\title{
Efektivitas Strategi Pembelajaran Klinik Metode SNAPPS (Summarize, Narrow, Analyze, Proba, Plan) Terhadap Penalaran Klinis Pada Maha- siswa Praktek Klinik : Systematic Review
}

\author{
1Hani Tuasikal, ${ }^{2}$ Raihany Sholihatul Mukaromah \\ ${ }^{1}$ Akademi Keperawatan Rumkit Tk III dr. J.A Latumeten, ${ }^{2}$ Stikes Bhakti Kencana Bandung \\ Email :hanituasikal@gmail.com
}

\begin{abstract}
Abstrak
Pendahuluan: Penalaran klinis (clinical reasoning) merupakan suatu keterampilan khusus yang harus dimiliki oleh seorang tenaga kesehatan salah satunya adalah perawat. Adapun strategi pembelajaran klinis yang dapat digunakan adalah metode SNAPPS.

Tujuan: Tujuan dari sistematik review ini adalah untuk mengetahui strategi pembelajaran klinik metode SNAPPS terhadap penalaran klinis pada mahasiswa praktek klinik.

Metode: Artikel dicari melalui Ebsco, Sciencedirect, PubMed dan Google search dilakukan menggunakan advanced search dengan kata kunciSNAPPS, clinical Reasioning and student clinical practice. Kriteria inklusi studi yaitu penelusuran dibatasi terbitan 2005-2015 yang dapat diakses fulltext dalam format pdf dengan desain RCT dan Quasi Experimentyang dilakukan pada mahasiswa praktek klinik. Intervensi berupa metode SNAPPS dengan pembanding metode usual and customary dengan outcome mengukur kemampuan penalaran klinis pada mahasiswa praktek klinik

Hasil: Hasil pembahasan menunjukkan bahwa metode SNAPPS lebih efektif daripada metode usualan dcustomary group dalam meningkatkan kemampuan penalaran klinis pada mahasiswa yang melakukan praktek klinik.

Kesimpulan : SNAPPS terbukti efektif dalam meningkatkan kemampuan mahasiswa untuk mengintegrasikan teori dan praktek dalam praktek klinis untuk memecahkan masalah.
\end{abstract}

Kata Kunci: SNAPPS, penalaran klinis, mahasiswa praktik klinik

\begin{abstract}
Introduction: Clinical reasoning (clinical reasoning) is a special skill that must be possessed by a health worker, one of whom is a nurse. This skill is one example of critical thinking skills. The clinical learning strategy that can be used is the SNAPPS

Objective: The purpose of this systematic review is to find out the clinical learning strategy of the SNAPPS method for clinical reasoning in clinical practice students.

Method: Articles searched through Ebsco, Sciencedirect, PubMed and Google search are performed using advanced search with the keywords SNAPPS, clinical Reasioning and student clinical practice. The study inclusion criterion was limited search of 2005-2015 which can be accessed fulltext in pdf format with Randomized Control Trials (RCT) and Quasi Experiment designs conducted on clinical practice students. The intervention in the form of SNAPPS method with the comparison of usual and customary methods with outcomes measures the ability of clinical reasoning in clinical practice students.

Results: The results of the discussion showed that the SNAPPS method is more effective than the usual and customary group methods in improving clinical reasoning abilities for students who practice clinics Conclusion: SNAPPS is proven effective in increasing students' ability to integrate theory and practice in clinical practice to solve problems.
\end{abstract}

Keywords: SNAPPS, clinical reasoning, clinical practice students

\section{Pendahuluan}


Pelayanan keperawatan merupakan bagian integral dari pelayanan kesehatan. Perawat idealnya mempunyai penalaran klinis dalam menghadapi setiap masalah pasien. Penalaran klinis adalah komponen penting dalam praktik keperawatan. ${ }^{1}$ Penalaran klinis (clinical reasoning) merupakan suatu keterampilan khusus yang harus dimiliki oleh seorang tenaga kesehatan salah satunya adalah perawat. ${ }^{2}$ Keterampilan ini merupakan salah satu contoh dari keterampilan berpikir kritis. Keterampilan ini dibentuk melalui latihan yang terus menerus melalui pemaparan dengan permasalahan klinis sejak masih mengikuti pendidikan.

Penalaran klinis akan menghasilkan suatu pertimbangan klinis yang baik apabila didasari dengan pemikiran yang kritis. Dari hasil penalaran klinis yang berdasarkan pemikiran yang kritis akan menghasilkan suatu diagnosis keperawatan dan penatalaksanan yang sesuai dengan penyakit yang diderita oleh seseorang.Kemampuan ini akan semakin tajam seiring dengan semakin seringnya seorang perawat menerapkannya dalam pelayanan kesehatan.

Keterampilan penalaran klinis bukanlah keterampilan yang dapat dipelajari dalam waktu singkat. Keterampilan ini membutuhkan waktu yang cukup lama, sehingga perlu ada pengulangan dan penajaman. Pengajaran penalaran klinis sebaiknya sudah dimulai sejak tahap preklinik agar mahasiswa memiliki dasar kemampuan berpikir yang kuat, meskipun akan sangat sering dilatih dan diajarkan pada pendidikan tahap klinik. Dengan demikian, pemaparan sejak dini diharapkan membuat kemampuan penalaran klinis semakin baik sehingga diagnosis atau tindakan keperawatan akan semakin tepat. ${ }^{3}$

Pembelajaran keterampilan penalaran klinis menjadi tantangan tersendiri bagi pengajar karena terbatasnya metode pembelajaran penalaran klinis yang tersedia. Sistem pendidikan tinggi keperawatan menyediakan proses pembelajaran yang komprehensif dengan menggunakan beberapa metoda pembelajaran di kelas, laboratorium dan lahan praktek di klinik.

Praktek Klinik merupakan suatu kegiatan yang dirancang untuk memberikan pengalaman belajar bagi mahasiswa dalam mencapai keberhasilan program pendidikan. Output yang diharapkan ketika mahasiswa melakukan praktek klinik yaitu perawat mampu mengambil keputusan secara efektif, cepat dan tepat dalam merawat pasien. Sehingga hal tersebut dapat melatih kemampuan berfikir kritis mahasiswa ketika menghadapi kasus yang dialami oleh pasien kelolaannya selama praktik klinik. Dalam menghadapi kebutuhan sistem pelayanan yang kompleks dan dinamis, praktik keperawatan membutuhkan perawat yang mampu berpikir dan mengambil keputusan secara efektif. Beberapa fenomena yang terjadi pada mahasiswa yang melakukan praktek klinik mempunyai kemampuan berpikir kritis dan kemampuan penalaran klinis rendah. Hal ini dapat dilihat pada saat melakukan praktek klinik mahasiswa belum mampu menggunakan keterampilan berpikir kritis dan kemampuan penalaran klinis terhadap permasalahan pasien kelolaanya.

Pendidikan klinik di rumah sakit merupakan tantangan pada pembimbing yaitu tetap memberikan pelayanan yang berkualitas dan efisien serta memasukkan komponen pendidikan yang bermakna bagi mahasiswa. Pendidikan keperawatan dalam upaya mempersiapkan calon professional dalam bidang keperawatan menyadari kondisi ini sehingga proses dalam pendidikan keperawatan juga mengandung proses pendidikan akademik dan proses pendidikan professional yang salah satunya dilakukan melalui pembelajaran klinik keperawatan.

Salah satu metode pembelajaran klinik yang digunakan untuk meningkatkan penalaran klinis pada pendidikan keperawatan adalah metode SNAPPS. SNAPPS merupakan salah satu metode mendidik peserta didik di klinik yang memungkinkan pendidikan memilih dan menerapkan cara mendidik yang sesuai dengan objektif (tujuan), dan karakteristik individual peserta didik berdasarkan kerangka konsep pembelajaran. ${ }^{4}$ Strategi SNAPPS dikembangkan berdasarkan teori pembelajaran kognitif dan reflektif. Pendekatan ini menekankan belajar aktif dan mendudukan proses bimbingan sebagai pengalaman aktif. Istilah SNAPPS merupakan akronim 6 langkah proses yaitu Summarize the case - Narrow the differential Analyze the evidence - Probe the preceptor Plan the management and follow-up - Self-di-

629 
rected study topic. Evaluasi SNAPPS menunjukkan bahwa mahasiswa yang dibimbing dengan SNAPPS dapat memberikan ringkasan kasus lebih rinci, kemudian mempresentasikan lebih banyak kemungkinan diagnosis dengan tingkat ketepatan diagnosis yang lebih tinggi. Mahasiswa yang memakai SNAPPS juga lebih baik dalam hal membandingkan hipotesis, menjelaskan ketidakpastian, mendiskusikan tentang manajemen dan mengidentifikasi topik yang harus dipelajari lebih lanjut. ${ }^{5}$

Berdasarkan banyaknya manfaat Metode SNAPPS yang telah dipaparkan maka Penulis merasa tertarik melakukan systematic review untuk menggali lebih jauh apakah pada mahasiswa praktek klinik Strategi Pembelajaran klinik Metode SNAPPS dapat meningkatkan Penalaran Klinis. Berdasarkan uraian diatas maka peneliti tertarik untuk mengetahui efektivitas strategi pembelajaran klinik metode SNAPPS terhadap penalaran klinis pada mahasiswa praktek klinik.

\section{Metode}

Desain penelitian ini menggunakan systematic review, dimana artikel penelitian dicari dengan beberapa cara pencarian dan kata kunci, kemudian dilakukan review dari semua artikel tersebut.

Kriteria inklusi dari artikel yang dicari yaitu : Tipe Studi ini menggunakan Randomized Control Trials (RCTs) dan Quasi-Eksperimental. Participant (P) dalam systematic review ini memfokuskan pada hasil-hasil penelitian yang dilakukan pada mahasiswa kesehatan yang sedang melakukan praktek klinik. Intervention (I) utama yang akan ditelaah dalam systematic review ini adalah metode SNAAPS sebagai salah satu bentuk strategi metode pembelajaran klinik. Adapun intervensi Compare (C) adalah metode biasa (usual and customary). Outcome (O) yang diukur adalah penalaran klinis mahasiswa praktek klinik

Kriteria Ekslusi dari artikel yang dicari yaitu: Kriteria ekslusi dalam systematic review ini adalah artikel yang berupa abstrak saja, artikel yang di publikasikan di bawah tahun 2005 dan artikel yang tidak menggunakan bahasa inggris.
Strategi pencarian literature yakni melalui Ebscho, Sciendirect, PubMed dan Google Scholar dilakukan menggunakan advanced search dengan kata kunci SNAPPS dan Clinical Reasioning. Setelah dilakukan search ditemukan 17 artikel pada Ebscho, 980 artikel pada Sciendirect dan 4 artikel pada Pubmed. Langkah selanjutnya melakukan screening untuk mendapatkan artikel yang full-text dalam bentuk pdf dan dari tahun 2005-2015. Pada langkah ini ditemukan 2 artikel pada Ebscho, dan 1 artikel pada Pubmed. Pencarian melalui google scholar dengan menggunakan kalimat Methode SNAPPS for Clinical Reasioning of Student clinical practice dan ditemukan ada 120 artikel. Tetapi karena keterbatasan waktu analisis penulis maka artikel yang diidentifikasi judulnya hanya sampai pada page 10 . Setelah diidentifikasi judulnya tidak ditemukan artikel yang dianggap sesuai dengan yang diinginkan peneliti.

Semua judul artikel yang dianggap sesuai dengan tujuan penelitian kemudian dijadikan satu dan dilakukan screening apakah judul pada artikel tersebut ada yang sama atau tidak sehingga didapatkan ada 5 artikel yang judulnya sama. Ke- 5 artikel ini kemudian di screening berdasarkan eligibility sesuai dengan kriteria inklusi.

Metode Pengkajian Kualitas Studi. Pengkajian kualitas studi menggunakan TOOLSCritical Appraisal Skills Programme (CASP) yang sudah terstandar untuk RCT dan Quasi-experimental. Penulis akses dari www.casp-uk.net. Critical Appraisal pada artikel dilakukan oleh satu orang yang sedang menjalani studi S2 keperawatan semester 1 di Universitas Diponegoro angkatan 2015. Hasil dari pengkajian ini hanya digunakan untuk melihat sejauh mana tingkat atau kualitas dari artikel yang ditemukan dan hasilnya tidak akan mempengaruhi hasil dari review.

Data akan diekstraksi dengan cara melihat isi artikel. Ekstraksi ini dilakukan dengan menganalisa data berdasarkan 4 tema yaitu Author, Participant, Intervention, dan Outcome. Ekstraksi data dilakukan oleh satu orang mahasiswa S2 keperawatan semester 1 di Universitas Diponegoro 2015.

Data-data akan dikumpulkan secara naratif. Sintesis data dilakukan dengan mengelompokkan data-data hasil ekstraksi yang 
sejenis sesuai dengan hasil yang ingin diukur untuk menjawab tujuan. Data yang sudah terkumpul kemudian dicari persamaan dan perbedaannya lalu dibahas untuk menarik kesimpulan. Penyajian data meliputi karakteristik artikel, intervensi metode SNAPPS terhadap penalaran klinis pada mahasiswa praktek klinik.

\section{Hasil}

Setelah dilakukan search didapatkan 1121 artikel lalu dilakukan screening untuk mendapatkan artikel yang full-text dalam bentuk pdf dan dari tahun 2005-2015, adapun artikel yang didapat sebanyak 21 artikel kemudian dilakukan screening kembali berdasarkan eligibility sesuai dengan kriteria inklusi.
Berdasarkan kriteria inklusi didapatkan 3 artikel. Sehingga hasil akhir artikel yang ada dilakukan review sebanyak 3 artikel.

Analisa dari 3 artikel itu menunjukkan 2 artikel menggunakan metode RCT (Randomized Control Trials) dan 1 artikel menggunakan Quasi-Eksperimental. 1 artikel dipublikasi pada tahun 2009, 1 artikel dipublikasi pada tahun 2012 dan 1 artikel dipublikasi pada tahun 2014 Berdasarkan Penilaian Artikel dengan Menggunakan Critical Appraisal Skills Programe (CASP) dihasilkan memiliki kualitas studi tinggi. Untuk mengetahui karakteristik data secara lengkap dapat dilihat pada table dibawah ini.

Tabel 2. Karakteristik Studi

\begin{tabular}{|c|c|c|c|c|}
\hline \multirow[t]{2}{*}{ Author } & \multirow[t]{2}{*}{ Participant } & \multicolumn{2}{|c|}{ Intervention } & \multirow[t]{2}{*}{ Outcome } \\
\hline & & Utama & Kontrol & \\
\hline $\begin{array}{l}\text { Wolpaw et all } \\
(2009)\end{array}$ & $\begin{array}{l}\text { Mahasiswa kedok- } \\
\text { teran tingkat } 3 \text { an- } \\
\text { tara April } 2004 \text { - } \\
\text { November } 2005 \\
\text { yang sedang } \\
\text { melakukan praktek } \\
\text { klinik } \\
\text { SNAPPS (n=66) } \\
\text { Usual-and-custom- } \\
\text { ary }(n=82)\end{array}$ & $\begin{array}{l}\text { SNAPPS (selama } 4 \\
\text { minggu) }\end{array}$ & $\begin{array}{l}\text { Usual-and-custom- } \\
\text { ary (selama } 4 \\
\text { minggu) }\end{array}$ & $\begin{array}{l}\mathrm{P}<.000 \text { (Sangat } \\
\text { Signifikan) }\end{array}$ \\
\hline Luc et all (2012) & $\begin{array}{l}\text { Mahasiswa kedok- } \\
\text { teran antara 2004- } \\
2005 \text { yang sedang } \\
\text { melakukan praktek } \\
\text { klinik. } \\
\text { SNAPPS ( }=19) \\
\text { Usual-and-custom- } \\
\text { ary ( } n=41)\end{array}$ & $\begin{array}{l}\text { SNAPPS (selama } 4 \\
\text { minggu) }\end{array}$ & $\begin{array}{l}\text { Usual-and-custom- } \\
\text { ary (selama } 4 \\
\text { minggu) }\end{array}$ & $\begin{array}{l}\mathrm{P}<0.016 \text { (Sangat } \\
\text { Signifikan) }\end{array}$ \\
\hline
\end{tabular}


Kittisak et all (2014)

\author{
Mahasiswa kedok- \\ teran tahun kelima \\ yang sedang \\ melakukan praktek \\ klinik. \\ SNAPPS $(n=90)$ \\ Usual-and-custom- \\ ary $(\mathrm{n}=93)$
}

$\begin{array}{lll}\text { SNAPPS (selama 4 } & \begin{array}{l}\text { Usual-and-custom- } \\ \text { ary (selama 4 } \\ \text { minggu) }\end{array} & \begin{array}{l}\mathrm{P}<0.016 \text { (Sangat } \\ \text { Signifikan) }\end{array}\end{array}$
minggu)

\section{Pembahasan}

Snapps adalah strategi pembelajaran klinik yang berpusat pada peserta didik untuk presentasi kasus untuk memfasilitasi ekspresi penalaran klinis dan ketidakpastian. Perawat harus memiliki keterampilan penalaran klinis yang efektif agar mampu beradaptasi terhadap perubahan lingkungan kerja yang serba cepat dan penuh tantangan. Lingkungan pelayananan keperawatan kritis membutuhkan kemampuan penalaran klinis yang tinggi dari perawat. Penalaran klinis sangat penting untuk mahasiswa yang sedang melakukan praktek klinik terutama dengan pengaturan waktu yang terbatas seperti di rawat jalan.

Istilah SNAPPS merupakan akronim 6 langkah proses (Wolpaw, 2009). yaitu Pertama, Summarize briefly the history and findings: Mahasiswa menjelaskan secara singkat riwayat dan hasil temuan pasien (anamnesis dan pemeriksaan fisik). Kedua, Narrow the differential to two or three relevant possibilities: Mahasiswa mempersempit diagnosis diferensial yaitu 2 - 3 kemungkinan yang relevan.

Ketiga, Analyze the differential by comparing and contrasting the possibilities: Mahasiswa harus menjelaskan hasil analisis dari diagnosis diferensial dengan membandingkan kemungkinan yang berlawanan. Keempat, Probe the preceptor by asking questions about uncertainties, difficulties, or alternative approaches: Mahasiswa diminta menggali pengetahuan dari preceptor dengan menanyakan hal-hal yang belum jelas seperti ketidakpastian dan kesulitan dengan berbagai pendekatan alternatif. Fase ini memungkin pembimbing memahami proses berfikir dan landasan pengetahuan mahasiswa dan sekaligus memberikan umpan balik dan informasi yang diperlukan oleh mahasiswa.

Kelima, Plan management to the patient's medical issues : Mahasiswa merencanakan manajemen untuk masalah medis pasien, mahasiswa melakukan diskusi dengan pembimbing tentang rencana manajemen atau intervensi khusus dan menyempurnakannya dengan bantuan masukan dari pembimbing.

Keenam Self a case related issue for self study: Fase terakhir adalah mahasiswa memilih materi-materi baru atau kasus isu terkait yang perlu dipelajari lebih lanjut untuk belajar mandiri tentunya dengan bantuan preceptor.

Pada intervensi yang ditemukan oleh reviewer terdapat 3 artikel yang menyebutkan bahwa metode SNAPPS dapat meningkatkan kemampuan penalaran klinis pada mahasiswa praktek klinik. Pada penelitian yang dilakukan oleh Wolpaw et all (2009) menunjukan bahwa mahasiswa yang menggunakan metode enam langkah snapps untuk presentasi kasus lebih sering mengungkapkan pertanyaan dan ketidakpastian tentang penalaran klinis daripada mereka yang berada di kelompok pembanding.6 Dua dari enam langkah snapps fokus secara khusus pada penalaran diagnostik, yaitu, Langkah 2 (Mempersempit diagnosis diferensial) dan Langkah 3 (Menganalisis diferensial). Proses terstruktur ini pada mahasiswa menyajikan penalaran diagnostik dan memberikan kesempatan langsung kepada pre- 
ceptor apa yang mahasiswa tidak dimengerti. Dalam presentasi kasus kelompok biasa atau tradisional lebih fokus pada data klinis dan rencana manajemen, ketidakpastian mahasiswa berpusat pada temuan klinis dan masalah manajemen obat.

Pada penelitian yang dilakukan oleh oleh Wolpaw et all (2012) menunjukkan bahwa ketika mahasiswa hadir berbagi ketidakpastian dengan preceptor, preceptor terlibat dalam interaksi pembelajaran memberikan umpan balik berdasarkan pada ketidakpastian mahasiswa. ${ }^{6}$ Ketika mahasiswa menyatakan ketidakpastian selama presentasi kasus, preceptor paling sering merespons ( $80 \%$ dari waktu), tanpa dari kelompok studi. Sedangkan penelitian yang dilakukan oleh oleh Kittisak et all (2014), menggunakan metode Quasi Experimental Trial ini mengukur 12 hasil (variabel dependen) terkait dengan mengungkapkan penalaran klinis dan ketidakpastian serta waktu presentasi. ${ }^{7}$

Berdasarkan review dari ketiga artikel ini dapat disimpulkan bahwa teknik SNAPPS ini sangat memudahkan mahasiswa dalam meningkatkan ekspresi penalaran klinis dan ketidakpastian selama presentasi kasus di rawat jalan. Mahasiswa dapat melakukan presentasi kasus dengan menggunakan teknik SNAPPS yang membuat setiap langkah lebih eksplisit dan memberikan tanggung jawab mahasiswa untuk mengekspresikan penalaran dan ketidakpastian klinis daripada preceptor memberikan tugas kepada peserta didik. Pelaksanaan SNAPPS ini dapat dikombinasikan antara pengembangan fakultas dengan perkembangan peserta didik secara lebih luas. ${ }^{8}$

Salah satu tujuan utama pengajaran klinis adalah untuk memfasilitasi pengembangan penalaran diagnostik pada peserta didik.9 Untuk melakukannya pertama, pembimbing perlu mengidentifikasi penalaran diagnostik mahasiswa untuk memandu pengembangan lebih lanjut. Dalam pengaturan kantor yang bergerak cepat perlu metode pengajaran dengan waktu yang efisien. Dengan prioritas sistem kesehatan difokuskan pada perawatan pasien dan produktivitas klinis, sedikit waktu tetap untuk mengajar. Metode pengajaran perlu mendorong singkat, saat mendidik antara kejadian perawatan pasien Sebuah teknik presentasi kasus yang berpusat pada peserta didik seperti SNAPPS merupakan tempat dari tanggung jawab memberikan wawasan kemampuan pelajar dari preceptor untuk pelajar.11

Hasil dari penelitian Wolpaw et al (2009) menunjukkan bahwa teknik SNAPPS yang berpusat pada peserta didik untuk presentasi kasus dapat meningkatkan ekspresi penalaran klinis dan ketidakpastian, bahkan dalam suasana tempat praktek yang sibuk menuntut dokter untuk berpikir cepat.11 SNAPPS menempatkan tanggung jawab pada peserta didik untuk merumuskan presentasi kasus yang memberikan wawasan kepada preceptor dalam pemikiran dan ketidakpastian mereka. Peran preceptor tetap penting untuk keberhasilan pertemuan pembelajaran, tetapi tidak berfokus pada mendapatkan diagnosis yang benar tetapi pada membimbing dan memajukan penalaran klinis pembelajar. $6,7,12$

Efektivitas strategi pembelajaran klinik metode SNAPPS dapat meningkatkan penalaran klinis, selain itu juga memiliki manfaat lain pada mahasiswa. Efek lain yang bisa dirasakan selain adanya peningkatkan penalaran klinis yaitu mahasiswa praktek klinik lebih sering mengungkapkan pertanyaan dan ketidakpastian tentang penalaran klinis daripada mereka yang berada di kelompok biasa. ${ }^{13}$

Kelebihannya yaitu teknik SNAPPS untuk presentasi kasus ini, dengan desain nya sangat dekat dengan struktur mahasiswa kedokteran, SNAPPS menuntut mahasiswa untuk meminta preceptor dengan mengajukan pertanyaan tentang ketidakpastian dan untuk memilih bacaan terkait kasus. SNAPPS membuat eksplisit harapan dan langkah-langkah lainnya dalam presentasi kasus kepada pelajar daripada preceptor, tanggung jawab untuk memastikan bahwa setiap langkah selesai. Selain itu, teknik SNAPPS memberikan kesempatan mahasiswa untuk mempersingkat ringkasan kasus selama temuan penting yang ada pada pasien, yang meninggalkan preceptor bebas untuk meminta informasi tambahan lainnya.

Metode SNAPPS ini baik untuk pengembangan peserta didik di fakultas. Meskipun keduanya penting, pengembangan fakultas lebih singkat, sedangkan pengembangan peserta didik lebih luas. Dalam kasus presentasi berpusat pada peserta didik seperti teknik SNAPPS, dosen harus permisif dan 
pelatih yang diperlukan. Sebaliknya, mahasiswa harus melakukan setiap langkah, dan pembimbing hanya perlu menanggapi. Mahasiswa mungkin pada awalnya perlu lebih diarahkan pembinaan, tetapi mereka mudah menjadi terampil menyelesaikan setiap langkah dari SNAPPS. Hasil dari penelitian ini menunjukkan perubahan dalam keseimbangan pelatihan ketika menerapkan strategi pengajaran. Pendidik medis sampai sekarang hampir seluruhnya berfokus pada pengembangan fakultas untuk meningkatkan pendidikan di pengaturan perawatan pasien, meskipun terlibat dokter sibuk dalam upaya pengembangan fakultas sulit. Dengan teknik SNAPPS, pengembangan mahasiswa adalah yang utama dan sama pentingnya dengan pengembangan fakultas di keberhasilan pelaksanaan metode pengajaran dan pembelajaran. ${ }^{14}$

Penelitian ini berlangsung dalam pengaturan rawat jalan. Satu tidak bisa menggeneralisasi temuan untuk disiplin ilmu atau pengaturan lainnya seperti layanan inap dirumah sakit. Perlu dilakukan penelitian lebih lanjut teknik SNAPPS pada rawat inap. Penelitian ini juga berfokus pada ekspresi penalaran diagnostik klinis dan ketidakpastian pada mahasiswa, bukan pada cara preceptor menanggapi mahasiswa. Kelebihan dari 3 artikel yang dilakukan review, yang dilakukan screening untuk mendapatkan artikel yang full-text dalam bentuk pdf. Artikel yang di review tahun nya up to date yaitu tahun 2014, 2012 serta paling lama tahun 2009, artikel yang dipilih berdasarkan eligibility sesuai dengan kriteria inklusi. Tiga artikel ini didapat merupakan hasil pencarian dengan membatasi metode pada Randomized Control Trial (RCT) dan Quasi Experimen. RCT dan merupakan tingkatan tertinggi dan baik dalam piramida evidence based practice. Dari ke tiga artikel yang didapat mempunyai populasi yang sama yaitu dokter sebagai preceptor dan mahasiswa yang sedang melakukan praktek klinik sebagai precepte dan sudah spesifik karena intervensi yang diberikan adalah sama yaitu metode SNAPPS dan kelompok pembanding yaitu metode biasa (Usual-and-customary group). 14 Kekurangan review ini adalah tidak semua artikel merupakan RCT, hanya 2 artikel yang merupakan RCT dan 1 artikel lain merupakan penelitian quasi eksperiment. Kata kunci yang digunakan hanya 3 : SNAPPS, Clinical Reasioning, Student clinical practice, sehingga kemungkinan ada artikel lain yang seharusnya bisa di review tidak bisa terdeteksi atau tidak muncul setelah dilakukan search. Hasil dari review artikel ini bias karena dilakukan oleh 1 orang, sehingga hasilnya kurang maksimal.15 Critical Appraisal pada artikel dilakukan oleh satu orang yang sedang menjalani studi S2 keperawatan semester 1 di Universitas Diponegoro angkatan 2015, kualitas Appraisal Study tidak dilakukan secara peer review sehingga subyektifitas masih sangat tinggi.

\section{Kesimpulan}

Teknik SNAPPS ini sangat memudahkan mahasiswa dalam meningkatkan ekspresi penalaran klinis dan ketidakpastian selama presentasi kasus di rawat jalan. Mahasiswa dapat melakukan presentasi kasus dengan menggunakan teknik SNAPPS yang membuat setiap langkah lebih eksplisit dan memberikan tanggung jawab mahasiswa untuk mengekspresikan penalaran klinis.

Metode SNAPPS dapat diaplikasikan pada mahasiswa keperawatan dalam meningkatkan kemampuan penalaran klinis. SNAPPS terbukti efektif dalam meningkatkan kemampuan mahasiswa untuk mengintegrasikan teori dan praktek dalam praktek klinis untuk memecahkan masalah. Mengenai hal ini penulis merekomendasikan kepada pihak pendidikan untuk dapat menerapkan strategi metode pembelajaran klinik ini dan disarankan kepada peneliti selanjutnya untuk melakukan penelitian lanjutan sehingga dapat memperkaya bukti-bukti yang ada secara ilmiah.

\section{Daftar Pustaka}

1. Banning, M. Clinical reasoning and its application to nursing: concepts and research studies. Nurse Educ Pract. 8, 177-183; 2008.

2. Ajjawi R, Loftus S, Schmidt HG, Mamede S. Clinical reasoning: the nuts and bolts of clinical education. In: Delany C, Molloy E (eds). Clinical education in the health professions. Chatswood: Churchill Livingstone; 2009.

3. Barrows HS, Tamblyn RM. Problem-based learning: an approach to medical education. New York: Springer; 1980.

4. Wolpaw T, Papp KK, Bordage G. Using SNAPPS to facilitate the expression of clinical reasoning and uncertainties: a randomized 
comparison group trial. Acad Med;84(4):517-524. PubMed PMID: $19318792 ; 2009$.

5. Norman G. 2005. Research in clinical reasoning: past history and current trends. Medical Education;39:418-427; 2005.

6. Kittisak, schwartz, wolpaw, bordage. Expressing clinical reasoning and uncertainties During a thai internal medicine ambulatory care Rotation: does the SNAPPS technique Generalize?. Early online : medical teacher; 2014

7. Kee F, Bickle I. Critical thinking and critical appraisal: the chicken and the egg? QJM; 97:609-14; 2004.

8. Kassirer JP. Teaching clinical reasoning: caseb a s ed and coached. A c a d e m i c Medicine;85:1118-24; 2010.

9. Wolpaw TM, Wolpaw DR, Papp KK. SNAPPS: a learner-centered model for outpatient education. Acad Med.;78(9):893-898. PubMed PMID: 1450761; 2003.
10. Wolpaw, Luc,. Papp, Bordage. Student Uncertainties Drive Teaching During Case Presentations: More So With SNAPPS. Academic Medicine, 2012; Vol. 87.

11. Bordage G. Elaborated knowledge: A key to successful diagnostic thinking. Acad Med. 1994;69:883-885

12. Eva KW. What every teacher needs to know about clinical reasoning. Med Educ. 2004;39:98-106.

13. Norman GR, Rosenthal D, Brooks LR, Allen SW, Muzzin LJ. The development of expertise in dermatology. Arch Dermatol. 1989;125:1063-1068.

14. Bordage G, Lemieux M. Which medical textbook to read? Emphasizing semantic structures. Acad Med. 1990;65:S23-S24

15. Connell KJ, Bordage G, Chang RW, Howard BA, Sinacore J. Measuring the promotion of thinking during precepting encounters in outpatient settings. Acad Med. 1999;74:S10-S12 . 